\title{
On Studies of Task Differentiation between Men and Women in the Scandinavian Iron Age
}

\author{
Louise Ströbeck
}

\begin{abstract}
Reiterated and cursorily criticised generalisations of attributes for male and female in grave goods, have since the first half of the nineteenth century created an oversimplified yet politically intricate image of a specific task differentiation between men and women in prehistory. Ideals of male and female roles and tasks in the interpreter's contemporary society have been described as universals in terms of binary oppositional pairs, or spheres, such as private/domestic-public. The dichotomies used for analysing and attributing male and female tasks have given preference to stereotypes, and the very formulation of the oppositional concepts for activity areas expresses ideological valuations of male and female. This article stresses the need for analysing the origin of concepts, and it seeks new and alternative ways of perceiving task differentiation.
\end{abstract}

Louise Ströbeck, Instilute of Archaeology, Lund University. Sandgatan 1, SE-223 50 Lund, Sweden.

The very first time sex was mentioned as a concept in studies of prehistory was in 1837 , in Mecklenburgisches Jahrbuch. In a programme with instructions for how surveys of prehistoric graves should be conducted, the authors expressed a desire that female and male artefacts found in the graves should be the point of departure for sex determinations of the deceased. The sword was classified as a typical male artefact, and especially the sewing needle was interpreted as a characteristic female artefact (Hjørungdal 1994:67, 1997:38). The weapon and jewellery pair was a second common material criterion of male and female in archaeological interpretations during the nineteenth century (Hjørungdal 1997:38). The Swedish archaeologist Tove Hjorungdal has pointed out the fact that weapons and needles/jewellery were established as material expressions for male and female sex identities before, or in the very beginning of, the vast surveys of grave remains during the first half of the nineteenth century (Hjørungdal 1994:67). Hjørungdal has also shed light on how the antiquarians of the $1800 \mathrm{~s}$ in their decree have used burials from prehistory to give roots and authority to a patriarchal gender ideology in their own society (Hjørungdal 1994:68ff). The antiquarians established sex differences which were tied to certain artefacts; things that identified the man as active in political life and as belonging to a public domain outside the home, and artefacts that defined the woman as part of the private domain, i.e. house and household, with no political power.

This sex determination, or more adequately sex attribution, of men and women 
was concurrent with a propaganda movement called the Gothic Revival. The movement was growing during the Victorian era, especially in the United Kingdom, from 1840 and onward. The Gothic Revival made the sewing needle into a symbol of eternal femininity, and the early antiquarians' definition of the sewing needle as characteristic for female sex in prehistoric burials confirmed the postulate of the typically feminine by pulling it back in time (Hjørungdal 1994:69f).

\section{THE FIRST WOMEN'S MOVEMENT, AND ITS LACK OF IMPACT ON ARCHAEOLOGY}

The number of unmarried women in society's upper classes increased during the nineteenth century, and demands for opportunities for these women to support themselves led to the struggle for women's right to come of age, to take a higher school certificate (Sw: studentexamen), and to study at the university (Carlsson \& Rosén 1980:335). Two celebrities in Scandinavian archaeology, Hans Hildebrand and Oscar Montelius, were engaged in the debate on women's emancipation in the late 1800 s and early 1900s. Hans Hildebrand and Oscar Montelius both occupied the office of Royal Antiquarian during their professional life. Hildebrand and Montelius introduced the method of typology, and Montelius established chronologies for the European prehistory. These two archacologists pleaded for women's emancipation, but they did not do it in their research. Hildebrand was conservative, and his involvement in the first women's movement was a commission he undertook as a member of the high and fashionable society. In 1884 he was elected chairman of one of the leading women's institutions in Sweden, the Fredrika Bremer Association (Welinder 1988:84ff).

Agda Montelius, wife of Oscar Montelius, succeeded Hildebrand as chairman. Oscar Montelius had a true enthusiasm for equality issues for men and women. He identified the inequalities and oppression of women in the institution of marriage (Arwill-Nordbladh 1998:4ff). Montelius' political position was liberal. He had a positive view of changes in society, but he was an evolutionist and said that changes would "happen" when society was ready for it (Welinder 1988:84ff).

Hanna Rydh is another renowned archaeologist from the early twentieth century. She was the first woman to take a doctoral degree in archaeology in Sweden, in 1919. Rydh was politically active, of benefit to a liberal party. In commissions and committees she drew others' attention to issues of female representation, inequalities concerning wages, the possibility of part-time work, and other matters related to women and the family. For a short period Hanna Rydh was a member of parliament. She was also chairman of the Fredrika Bremer Association for twelve years. Although active in the movement for emancipation of women, Hanna Rydh - like her archaeologist predecessors - supplied a stereotyped picture of the Late Iron Age woman as a housewife belonging to the home and the household (Arwill-Nordbladh 1987:86,99, 1998:16ff).

The sex roles, or task differentiation, postulated by the early antiquarians remained intact during the time of the first women's movement, despite the fact that influential archaeologists held prominent positions in this movement. In the following decades, from 1910 to 1970 , sex determinations based on grave goods were hardly being made in Scandinavia. Only a few interpretations were made of social relations during this period (Hjørungdal 1992:32ff).

\section{THE SECOND WAVE OF FEMINISM,} AND ITS PROJECTION OF

\section{CONTEMPORARY GENDER} IDEOLOGY ON PREHISTORY

The modern or second women's movement initiated feminist research. The theoretical point of departure was female Marxists' criticism of the terminology used by Marx. The critics argued that women's unpaid work 
at home was excluded per definition when profit in production/paid work was analysed and discussed. In the 1970 s feminist Marxists called for explicit studies of task differentiation between men and women. The inequalities between the sexes were said to be found in the design of task differentiation, and the overall aim was to make the woman and her work visible, and make her into an agent (Holmberg \& Lindholm 1989:225ff, 237; Carlsson et al. 1993:132ff). Archaeological research was affected by this political endeavour through other disciplines, such as social anthropology and history. Archaeologists presented, in accordance with the feminist ideals of equality, interpretations of female farmers, female merchants and female sailors (Dommasnes 1987:65ff; Stalsberg 1988:33ff).

The Norwegian archaeologist Liv Helga Dommasnes published an article called Male/ female roles and ranks in Late Iron Age Norway, in 1987. The article appeared in a publication from a workshop called Were they all men? An examination of sex roles in prehistoric society, which was held in Norway in 1979. Dommasnes elucidates sex roles and women's rank in different areas of Norway in the Late Iron Age. Her interpretation aims to create an alternative picture of the Iron Age women. However, Dommasnes' method of describing and analysing activities and male and female contributions reinforces traditional sex roles, and cements the dichotomy of public versus private/domestic.

Dommasnes bases her statements on interpretations of grave finds. The sex determinations of the deceased are based on artefacts interpreted as characteristic of males and females respectively; an oval brooch indicates that the deceased was female, and weapons like swords, axes or spearheads are criteria of a male grave. Dommasnes assumes that the tools found in the graves show what kind of work the deceased had done in life. She notes that in Sogn, western Norway, women have been buried with both female artefacts, like textile implements, and male tools like axes, files and arrowheads. Dommasnes postulates that women buried with male tools have taken over tasks which were formerly performed by men. The reason women carried out tasks that traditionally were not regarded as appropriate for women was, according to Dommasnes, that men had left the farm for trade, piracy and warfare in foreign territories. Imported goods in Sogn indicate that the region had contacts with foreign territories, and the author refers to written sources when she says that it was the men who travelled long distances (Dommasnes 1987:65ff). When men's time and effort were spent elsewhere than at the farm, especially during the Viking Age, the women left at home apparently took responsibility for the farming and consequently the women also took over certain male attributes.

Dommasnes says that it is even possible to make statements about the status of men and women in the Late Iron Age in Norway, on the basis of the ratio of male/female graves. It is regarded as indicative of a high ranking individual in the grave, if the deceased is buried in a grave that is visible for archaeologists through grave furnishings or markers above ground (Dommasnes 1987:69,71). Dommasnes suggests - in accordance with her study of the ratio of male/female graves -that more women obtained high rank in the ninth century than in any other period, and that the number of high ranking women was greater in the coastal areas than in the interior during all centuries from the $7^{\text {th }}$ to the $10^{\text {th }}$ (Dommasnes 1987:71ff). The interpretation is consequently that women stepped in and took over typical male roles at the farm during the men's absence, and that this rendered the women a higher social status (Dommasnes 1987:76). If this analysis was meant not only to attribute the Late Iron Age woman new tasks, but also to make her an active person in the development of the society, then the interpreter has missed the fact that women were still described as lacking influence and 
power in society and history. Women were found in what formerly had been interpreted as ruling contexts, but the contexts of power and ruling had changed and moved. According to the designation and characterisation of the Viking Age, the men had taken the power with them. The Iron Age women consequently still lacked influence over the development of society in their new roles in feminist research.

Dommasnes does not use the terms "public" and "private/domestic" explicitly, but they are implicitly integrated as activity areas in her interpretation. If Dommasnes had analysed the concepts that are latent in her survey, she would have found that they have a context. "Public" and "private/domestic" are defined under certain historical circumstances and are marred by the social, political and cultural valuations of the society in which the concepts are defined. The valuations inherent in the concepts of public and private/domestic contain preconceived ideas about the relations between the sexes, which originate from contemporary gender ideology (Moore 1988:21ff; Arwill-Nordbladh 1994:35ff; Prestvold 1996:18). In Dommasnes' interpretation, women's social rank changes in relation to the men's activities. The private/ domestic sphere appears as static, except when it transforms in relation to, or is affected by, changes in the public sphere. This is due to the types of analytical categories with which the author operationalizes male and female.

Dommasnes does not discuss or analyse the background of the task differentiation she describes. It may therefore be said that the absence of problematization of the background indicates an underlying assumption that the task differentiation is based on biological circumstances, i.e. women's biological reproduction, and that the formation of relations described in the interpretation are universal. There was, however, a debate during the 1970s and the 1980s concerning the biological determination and the cultural designation of the characteristics of male and female. After having claimed the existence of a universal pattern for male and female activities in accordance with the dichotomy public-private/domestic - primarily based on women's biological reproductive role anthropologists retracted this postulate and stressed the importance of cultural images and variability for male and female roles and tasks (Rosaldo \& Lamphere 1974:1ff; Rosaldo 1980:389ff; Moore 1988:1ff).

\section{PROCEEDINGS IN GENDER STUDIES OF TASK DIFFERENTIATION}

It seems that the basic assumptions and interpretations of male and female and of task differentiation between the sexes in archaeological studies, have not changed much since 1837. What appears to be the result of the same way of analysing gender and task differentiation does, however, correspond to separate gender ideologies in the different interpreters' contemporary societies. The early antiquarians did not study task differentiation especially, but male and female. Male and female characteristics were, however, often described in activities. During the neoGothic era, in Scandinavia the decades after 1850, the Victorian gender ideology formed the image of the Late Iron Age patriarchal housewife, associated with domestic tasks (Arwill-Nordbladh 1991:64). The Viking Age man was presented as a husband with authority, a peasant and a Viking (ArwillNordbladh 1991:54ff). Much of the feminist research, on the other hand, focused on interpretations of task differentiation between the sexes, and made visible the stereotypes in interpretations of male and female activities in previous research. Most feminists, however, did not analyse the categories mainly private/domestic-public - which they used in their studies. Their meaning or definition was to a great extent identical with the descriptions of male and female in traditional research. Instead feminist researchers attempted to break traditional boundaries by 
letting certain persons, preferably women, shift roles or spheres in prehistoric societies.

How can archaeologists proceed with studies of task differentiation? How is it possible not to project the gender ideology from the preceding centuries onto prehistoric relations, when interpreting images of male and female in ancient societies? The Swedish archaeologist Elisabeth Arwill-Nordbladh has issued a usage of new concepts more adequate for gender research than the ones used before (Arwill-Nordbladh 1994:35ff). While waiting for these new concepts to be presented, and perhaps as a first step to formulating alternative analytical tools in gender studies of task differentiation, I would like to discuss some proposals of how to think in different ways than previously about task differentiation.

\section{STUDYING ASYMMETRY, WITHOUT IMPLICATIONS OF HIERARCHY}

Gender researchers have levelled criticism against many of the concepts in dichotomies, which are frequent in analyses of male and female. According to the critics, images of inequalities between men and women and ideas of women as passive and oppressed are often applied to prehistoric times, through the use of some specific reiterated analytical themes expressed in dichotomies like natureculture, private/domestic-public and production-reproduction (Moore 1988:21ff; Arwill-Nordbladh 1994:36). These oppositional categories have been used to analyse and illustrate differences between men and women. But as I stated earlier, the dichotomous concepts imply power relations through their construction as pairs and through their definitions. In categories such as private/ domestic-public and nature-culture, the terms asymmetry and hierarchy are integrated into each other, and the oppositional poles can perhaps be said to be explained by each other.

The concept of asymmetry, however, originally denotes horizontal differences between individuals or among groups of inhabitants, while hierarchy describes vertical differences, that is, power relations and inequalities. Asymmetry and hierarchy may be linked in reality, but the two phenomena probably appear as a pair to a greater, or to a lesser, extent in certain societies than they do in other societies. It is also likely that the co-variation between horizontal and vertical differences among prehistoric inhabitants finds widely different expressions in various cultures (Thurén 1996:74). Gender studies that do not separate asymmetry from hierarchy risk overlooking interesting questions about the design of gender relations and power relations in the gender organisation in prehistoric societies. To separate asymmetry from hierarchy in theoretical reasoning, could be a first step to restrict preconceived ideas of power relations in gender research and to create prerequisites for many and varied gender studies. An important question to answer here is consequently where the mixup and confusion over the concepts of asymmetry and hierarchy derive from.

The bipolar categorization paired with hierarchical thinking, was characteristic of organizing the world in the 1800 s and the first part of the twentieth century. It is, however, possible to trace the formulation of the dichotomies to different contexts in history. Private-public originates from ancient Greece. Aristotle described the household, oikos, as an antipole to the state. The dichotomy has been revitalised and at the same time modified on occasions in history, but two characteristics associated with the concepts have survived since the first definition. The first is that the family or household is formed in relation to the state, as its counterpart. The second is that the differences between the father and the rest of the family - differences that legitimate his superiority - are determined by nature (Arwill-Nordbladh 1994:36f). The dichotomy productionreproduction has its origin in Marxism (Arwill-Nordbladh 1994:43).

Researchers should reflect more on the 
meaning of analytical terms and concepts, in order not to uncritically project organisational principles and norms in contemporary societies onto prehistoric cultures. If researchers continue to apply previously presented models for analysing gender roles and gender images on past societies, they risk taking hierarchical dimensions in gender relations for granted, and they will tell the prehistory we already know from our contemporary gender ideology: the story of the active man, and his passive, inferior wife. It is of course free for anyone to study power relations between men and women in prehistory, but the researcher should in that case make clear for himself/ herself and for the readers what he/she means by power, and he/she should declare that the postulates are based on interpretations made by the author referring to his/her valuation of the differences he/she discerns in the archaeological material.

Attempts have been made to twist and conflate conventional associations between some central analytical concepts in gender research and power relations between men and women. In these studies authors have pleaded for women's informal influence over political decisions in their capacity as wives and mothers to men active in the public sphere, and researchers have made attempts to interpret the private/domestic sphere as attributed with the characteristics of the public sphere (Øye 1990:446). The authors of such studies are obviously aware of the seldom emphasised, although present and implied, hierarchical organisation between men and women in archaeological interpretations of gender relations. To write a prehistory that generates images quite contrary to the ideas of male and female in traditional research, makes visible the intricate connection between concepts, their construction, meaning and context. Creating alternative pictures of prehistory with the same terminology and categories as in previous research will, however, limit the alternative interpretations of the design of gender relations (Prestvold
1996:24). The generalisations and the stereotyped categorization will still characterise these alternative pictures, and the background of the differentiation into two spheres will remain unproblematized and will not be modified by this kind of reassociation of male and female.

\section{DECONSTRUCTING SPHERES, AND CREATING RELATIONS OF CO- OPERATION}

There is more than one way of analysing and describing past cultural or societal organisations in terms that do not presuppose hierarchy and prescribe subordination. There are, however, at least two essential items in research connected to each other, which should be regarded when studying male and female activities, and especially when the aim is to create new and alternative ways of describing task differentiation between men and women in prehistory. I have already stated that the point of departure for studying male and female activities should be a critical evaluation of different analytical concepts' inherited implications of power relations. This evaluation should be completed with an analysis of the very tasks men and women actually are likely to have performed in accordance with the source material, and what the interpreter's association between artefact and gender role or task is based on. The two moments emphasise that images, attributes and activities associated with men or women in a given context have to be investigated, not assumed. This corresponds to the definition of gender as a socially and culturally dependent variable, possible to express in several different images.

One way of avoiding projection of the contemporary value-loaded sex role pattern onto prehistoric societies is to operationalize questions of male and female by studying many activity areas. Instead of forcing the various activities of any society into two diametrical spheres, it would be possible and probably even fruitful to study more than a 
few extensive activity areas. I imagine this multiplication of activities as a form of deconstruction of the spheres of private and public, and not just a simplified labelling of some specific tasks within the public and domestic domains. This deconstruction would be even more effective if researchers, at least in the beginning, made obvious attempts to transcend the oppositional categories of private/domestic and public through a deliberate creation of activity areas which overlap and integrate the previously favoured spheres of private/domestic and public. In these alternative efforts to analyse task differentiation, women do not have to be automatically associated with domestic activities because of their sex. The fact that it is women who give birth to children, does not necessarily mean that women also do all the sewing, washing and cooking in the various cultures they are living in. The division of male and female into more than two spheres also contributes to refute the idea that men do all the tasks that women do not perform, and vice versa. The possibilities for recognising that men and women have conducted the same kinds of activities are probably also better with a multi-faceted model for task differentiation, than with a "two-sphere" model that implicitly identifies activities with sex roles.

Making shelter for cover and protection could be a potential alternative activity area or category in a new kind of research on task differentiation. (The term "shelter" was proposed by Dr. Elisabeth Iregren, in a discussion.) Paying attention to activities such as making shelter, brings together various tasks which have been interpreted as either male or female in previous research. Making shelter can include tasks like sewing clothes and building houses. Both tasks are performed in a sphere that could be called "at home"; not domestic perhaps, but at least at home. It would, however, still be easy to give way to the traditional dichotomous thinking about the sexes in a study like that, if the study of making shelter solely dealt with the task of running a needle through pieces of cloth or working with an axe on timber. There is consequently a need to develop the suggested perspective further, and this brings us to a critical analysis of the definitions of activities.

Analyses of the definitions of already gender-attributed tasks in archaeological research have shown how former definitions of activities have been restricted to the performance of one type of work within an activity which in fact consists of many tasks (Wright 1991:198ff; Stig Sørensen 1996:51ff). A survey of what the types or sequences of work are that have been interpreted as crucial to the performance of an activity, will presumably show that it is not just the preserved artefacts but also the interpreters' images of how activities are constituted, that have made the archaeologists regard them as significant. Hunting, farming/ fieldwork and metalwork are mostly interpreted as male activities in traditional research, and the three have been identified with tasks within these activities that focus on the types of work that are associated with a male agent. Hunting has come to be identical with the killing of game, fieldwork during the Iron Age is synonymous with steering the plough from the rear, and metalwork is described as casting, forging and smithing the metal (Olsen Bruhns 1991:427; Stig Sørensen 1996:51ff). These more or less explicit definitions of hunting, fieldwork and metalwork probably derive from the interpreters' associations between killing, steering and hammering, and male courage, endurance and physical strength. It should be noted that these activities have been interpreted as characteristic of Scandinavian prehistory, according to the designations of prehistoric epochs: the Stone Age (the Hunter Stone Age, and the Farmer Stone Age), the Bronze Age and the Iron Age. If the other tasks necessary for the performance of the postulated crucial tasks in the activities mentioned above should be regarded, hunting would be analysed as 
an activity including tasks such as looking and spying for game to hunt for meat supply and/or for their supply of fur. The possible calling of game with characteristic sounds or cries, and the strategic driving of the chosen game towards an abyss or in the direction of the persons who intend to kill the animal(s), are tasks that also have to be conducted if there is going to be a successful hunt at all. Leading the oxen to the field, hitching them up and walking in front of them, guiding the animals if needed, and sowing, are all tasks that are essential when fieldwork and ploughing are carried out, besides the steering of the plough from the rear (Olsen Bruhns 1991:427). In addition to casting and forging, metalwork involves tasks that are connected with prospecting, producing firewood and charcoal, and shaping and decorating the objects (Stig Sørensen 1996:56). If we return to the example of the making of shelter, the redefinition of activities I have argued for would mean that sewing clothes should include the making of cloth for a dress. The activity of building houses should on the other hand include tasks such as collecting and obtaining the different materials required for building walls, roof, etc. The building materials from different environments have also been handled with different techniques, which rely on various kinds of knowledge, skill and experience.

A redefinition of several activities is called for in order to do studies of the relations between men and women, and not between male and female spheres, in prehistory. Studies in which activities are analysed as being composed of sequences of tasks or concurrently executed tasks dependent on each other, break up the stereotyped dichotomous categorization of male work contra female work. They pave the way for gender studies of task differentiation which notice age-linked sexual differentiation, family group activity, co-operation between men and women, and the existence of non-gendered tasks and activities (Olsen Bruhns 1991:427;
Wright 1991:198ff). But doesn't this kind of analysis eliminate the grounds for studying task differentiation between men and women in prehistory? The answer is that it will only blur the often simplified picture of a rigid differentiation of work and activities that has been presented in most archaeological texts. It will wipe out that picture's great resemblance to the Victorian bourgeois gender ideology, which lingers on in societies in the West.

\section{ELUCIDATING PREVIOUSLY FOR- GOTTEN AND NON-GENDERED WORK}

Although much of the research and interpretations of male and female roles and gender images in prehistory has been occupied with analyses of male and female work and activities, many activities in the past still remain to be problematized from a gender perspective. The reason for this is probably partly that the ambiguous find circumstances make it impossible to establish connections between some activities and either males or females, and partly because there is no specific association between a particular kind of activity and man or woman according to the interpreter's contemporary gender ideology.

It is interesting to note that one activity that is hardly ever mentioned in studies of task differentiation, based on interpretations of grave finds, is the construction of the graves. There are many tasks connected with the burial, the construction of a grave and in some cases the building of markers above the grave of the deceased. The Swedish archaeologist Agneta Lagerlöf (Bennett) has more or less intentionally made way for questions of who built the graves. Bennett has been able to show that constructions of stone over graves in the area around Lake Mälaren, in eastern Sweden, present gender-specific traits during the Migration period. Stone constructions over graves with deceased who have been sexdetermined as women - according to the artefacts found in the graves - are tidier and 
have a more distinct design than stone constructions above graves where the individuals have been sex-determined as men. A great part of the women's grave markers consist of stones not more than 0.3 meter in diameter, and Bennett shows that the center of the grave marker varies more in shape among women's graves than among men's graves. A round stone appears to be reserved for women in this geographical area during the Migration period (Bennett 1987:45,131f). Bennett does not present any background for the difference between the men's and women's markers of stone that she discusses. It is, however, possible to reflect over the question of whether the differences are due to the gender of the deceased, or the gender of the person(s) who built the grave. Perhaps both proposals are correct, perhaps it was women who built women's graves and men who built men's graves. If Bennett's conclusions about the differences between men's and women's grave markers are pushed further, they may end in explanations referring to male and female biological traits of physical strength and carefulness. This attempt to problematize the graves' design is, however, an effort that should be noticed and developed further in research on task differentiation. Future analyses should, though, pay attention to the risk of referring to social and cultural characteristics of the performance of tasks and/or composition of graves as male and female hereditary traits.

Most studies of task differentiation between men and women have interpreted the implements in the graves in a secular context. Grave goods can include implements, but the association of these to contexts of work performed by the deceased in life are due to the archaeologists' interpretation of the artefacts' function. Tove Hjørungdal is among the archaeologists who has pointed out new aspects of gender research, by elucidating the relationship between men and women in Scandinavian prehistoric cult and mythology on the basis of tools in graves (Hjørungdal
1991:98,105). Hjørungdal problematizes the traditional meaning of the concept of production. The term "production" has been defined as material production, but Hjørungdai uses the term to describe what she calls the "total production". The total production includes both material production and symbolic production (Hjorungdal 1991:113). In a survey of gender images during the Roman Iron Age and the Migration period in Norway, Hjørungdal has paid attention to the fact that only a selection of implements has been found among the identifiable grave goods. She raises the question of whether this could indicate that the tools are to be associated with a context beyond the specific secular functional task (Hjørungdal 1991:101). Hjørungdal argues that women were attributed artefacts that can be associated with life, not because of women's role as childbearer but due to women's performance of a fertility rite (Hjørungdal 1991:113). A knife traditionally interpreted as a tool for leather working may be linked to a phallus cult/fertility cult, where a woman has been the person officiating the cult. The knife might be associated with the preparation of the phallus from a ritually slaughted stallion, which takes a cental place in the rite (Hjørungdal 1991:104). Hjørungdal also mentions the possibility that implements like spindle-whorls, arrowheads and smith's tools among the grave goods can be interpreted as symbols for persons in prehistoric mythology in Scandinavia. The implements do not necessarily have to be identical with the deceased person's tasks in life (Hjørungdal 1991:101ff).

\section{MAKING THE INDIVIDUALS VISIBLE}

The deconstruction of two spheres and the replacement of them with many activity areas, and the redefinition of activities into sequences or concurrently executed tasks, may be completed by viewing prehistoric populations as consisting of interacting individuals, instead of supplementing categories of men and women. This would make it more difficult 
for preconceived ideas of a certain sexdetermined task differentiation, and sexdetermined hierarchical relations, to gain foothold in gender studies of task differentiation. To simply disregard the sex of the prehistoric individuals in studies of task differentiation would, however, not be possible. The basic assumption or hypothesis in gender research is that the individual is characterised and manifested by images, called gender, and sex and male or female are some aspects of the individual. Characteristics of male and female may not be dismissed without first being regarded, even if the purpose of the study is to prove that they are not the primary or even important principles for structuring the performance of tasks.

It seems that this approach would favour a manner of procedure where the interpretation of tasks precedes the determination of sex in the research process. In a burial context this is not always possible, at least not if the sex determination of the individual is based on artefacts which concurrently are interpreted as implements, such as swords and other weapons, and spindle-whorls. To determine the sex of a deceased individual with specific artefacts as a point of departure, and at the same time attribute these artefacts as male or female in accordance with an archaeological sex determination, is in any case not a satisfying procedure.

If the individuals are going to be interpreted as men and women after their tasks have been analysed, the risk of contamination of prehistoric gender ideology by contemporary gender images still remains, namely through the interpreter's association to male or female sex on the basis of the already interpreted tools and utensils among the grave goods. To determine the sex of the deceased by studying criteria in their skeletal remains may therefore appear to be a more suitable method than sex determination based on artefacts, in gender studies of task differentiation. The physical-anthropological sex determination can, however, be questioned as well. Gender critics have problematized the general disproportion of sex-determined men in prehistoric populations, by considering it as a probable effect of the physical anthropologists' contemporary images of men's and women's different constitution and different life circumstances. Most procedures of sex determination are based on physical anthropologists' preconceptions that males are large and robust, while females are small and gracile. The size can, however, be affected by cultural and environmental factors. In a range of measurements of the skeleton there is an overlapping between the sexes that may not be solely due to hereditary biological traits, but also to the skeleton's response to external forces and stimuli such as the performance of tasks (Donlon 1993:98,101). Physical anthropologists of today agree, however, that the best criterion to use for sex determining human skeletons by the osteological method, is based on the shape of the pelvic girdle (Donlon 1993:99; Götherström et al. 1997:73). Differences in the pelvis due to men's incapability to give birth to children and women's ability to do this, are considered to indicate whether the skeleton belongs to a man or a woman. But the pelvic girdle is also an anchor for several muscles of the lower limbs, which means that there is risk that all morphological differences in the pelvic region are not a result of differential reproductive function. Some of the characteristics of the pelvis may consequently also be mechanicalfunctional (Götherström et al. 1997:72). The question that follows with these statements is how physically active women or physically passive men are to be recognised in skeletal samples, if there is not an interpretation of a prehistoric gender ideology and/or contemporary gender images that embraces the possibility of a varied and complex task differentiation between men and women.

It appears that the method for reducing presuppositions of male and female activities - and hierarchical relations between those - 
by analysing men and women as individuals, is limited. This is at least the case when the endeavour is to establish an interpretation of a gendered task differentiation. The best way to write about men's and women's tasks would be to let different researchers carry out physical-anthropological sex determinations of skeletal remains and analyse the function or meaning of artefacts among the grave goods separately, and bring the interpretations of sex and task together and formulate a synthesis of them. A synthesis which is sensitive to ambiguities and deviations, and which gives priority to an analysis of multiplicity rather than adjustments of interpreted characteristics for the purpose of making different cases conform to set images and stereotypes.

\section{CONCLUSION}

This article can be regarded as a contribution to how to begin to think in different ways from previously with respect to task differentiation between men and women. It is meant to show how the gender perspective is able to make way for alternative pictures of male and female in prehistoric task differentiation. Readers may object that the deconstruction and emphasis on variation are typical phenomena of post-modern gender theory, and are just as contaminating as traditional and early feminist research. The fact remains, though, that traditional and feminist research have not been able to break with the stereotyped interpretation of typical male and female tasks or work. Hopefully the alternative way of viewing differentiation within the gender perspective will increase our knowledge and deepen our understanding of the organisation of tasks during prehistory, as it attempts to avoid simplistic models and generalising concepts.

\section{English revised by Laura Wrang.}

\section{ACKNOWLEDGEMENTS}

I would like to thank the Gender-seminar held in Lund on 12 th of April 1997, Dr: Elisabeth Iregren and Professor Roberta Gilchrist for their comments on the proposals and the ideas in this paper.

\section{REFERENCES}

Arwill-Nordbladh, E. 1987. Det dubbla budskapet hos Hanna Rydh. Kvinner i Arkeologi i Norge 4:1987. Pp. 83-102.

- 1991. The Swedish Image of Viking Age Women: Stereotype, Generalisation, and Beyond. In: Samson, R. (Ed). Social Approaches to Viking Studies. Glasgow. Pp. 53-64.

- 1994. Begriper vi begreppen? Om androcentrismen i några vanliga analytiska begrepp. META 1:1994. Pp. 35-47.

- 1998. Genuskonstruktioner i nordisk vikingatid. Förr och nu. GOTARC. Gothenburg Archaeological Theses. Series B No 9. Göteborg. Diss.

Bennett, A. 1987. Graven - religiös och social symbol: strukturer i folkvandringstidens gravskick i Mälarområdet. Theses and Papers in North-European archaeology 18. Stockholm. Diss.

Carlsson, C., Esseveld, J., Goodman, S. \& Widerberg, K. 1993. Om patriarkat: en kritisk granskning. In: Ericsson, C. (Ed). Genus $i$ historisk forskning. Lund. Pp. 131-145.

Carlsson, S., Rosén, J. 1980. Svensk historia, del 2; Tiden efter 1718. Lund.

Dommasnes, L. H. 1987. Male/female roles and ranks in Late Iron Age Norway. In: Bertelsen, R., Lillehammer, A. \& Næss, J.-R. (Eds). Were they all men? An examination of sex roles in prehistoric society. Acts from a workshop held at Utstein Kloster, Rogaland 2.-4. November 1979. AmS-Varia 17. Stavanger. Pp. 65-78.

Donlon, D. 1993. Imbalance in the Sex Ratio in 
Collections of Australian Aboriginal Skeletal Remains. In: Du Cros, H. \& Smith, L. (Eds). Women in Archaeology. A Feminist Critique. Canberra. Pp. 98-103.

Götherström, A., Lidén, K., Ahlström, T., Källersjö, M. \& Brown, T. A. 1997. Osteology, DNA and Sex Identification: Morphological and Molecular Sex Identifications of Five Neolithic Individuals from Ajvide, Gotland. International Journal of Osteoarchaeology, vol. 7:1997. Pp. 71-81.

Holmberg, C. \& Lindholm, M. 1989. Feministisk teori: traditioner, riktningar, teoretiker. In: Månson, P. (Ed). Moderna samhällsteorier. Stockholm. Pp. 218-247.

Hjørungdal, T. 1988. Kan man identifisere kvinners arbeid utifra graver? In: Iregren, E., Jennbert, K. \& Larsson, L. (Eds).Gravskick och gravdata: rapport fràn arkeologidagarna 13-15 januari 1988. Report Series, University of Lund, Institute of Archaeology. Lund. Pp. 115-119.

- 1991. Det skjulte kjønn. Patriarkal tradisjon og feministisk visjon $i$ arkeologien belyst med fokus på en jernalderkontekst. Acta Archaeologica Lundensia Series in $8^{\circ}$. Lund. Diss.

- 1992. Från hjältinnor till genus. Forntid, arkeologi och könsmakt. Häften för kritiska studier 2:1992. Pp. 32-42.

- 1994. Antikvarien, synålen och svärdet. Forskningshistoriska aspekter på gravar och könsideologi. In: Goldhahn, J. (Ed). Kontaktstencil XXXVII. Teori och praktik. Pp. 67-71.

- 1997. Engendering antiquities. Some inquiries into the construction of archaeological scholarship in a nineteenth century context. In: Karlisch, S. M., Kästner, S. \& Mertens E. M. (Eds). Vom Knochenmann zur Menschenfrau. Feministische Theorie und Archäologische Praxis. Bericht über die 4. Tagung des Netzwerks archäologisch arbeitender Frauen in Stralsund 1996. Pp. 36-48.
Moore, H. 1988. Feminism and Anthropology. London.

Olsen Bruhns, K. 1991. Sexual Activities: Some Thoughts on the Sexual Division of Labor and Archaeological Interpretation. In: Walde, D. \& Willows, N. D. (Eds). The Archaeology of Gender: Calgary. Pp. 420-429.

Prestvold, K. 1996. Distant voices? Still lives? Conflict, Contradiction and Active Negotiation in Everyday Life: Female Roles, Status and Lives in the Past. Kvinner i Arkeologi i Norge 21:1996. Pp. 13-31.

Rosaldo, M. 1980. The use and abuse of anthropology: reflections on feminism and crosscultural understanding. SIGNS 5.3. Pp. 389417.

Rosaldo, M. Z., Lamphere, L. 1974. Woman, Culture and Society. Stanford.

Stalsberg, A. 1988. The Implications of the Women's Finds for the Understanding of the Activities of the Scandinavians in Rus' during the Viking Age. Kvinner i Arkeologi i Norge 5:1988. Pp. 33-49.

Stig Sørensen, M. L. 1996. Identifying or Including: Approaches to the Engendering of Archaeology. Kvinner i Arkeologi i Norge 21:1996. Pp. 51-60.

Thurén, B-M. 1996. Om styrka, räckvidd och hierarki, samt andra genusteoretiska begrepp. Kvinnovetenskaplig tidskrift nr: 3-4. Pp. 6985.

Welinder, S. 1988. Svensk arkeologis guldålder och kvinnosaken. Kvinner i Arkeologi i Norge 5:1988. Pp. 84-90.

Wright, R. P. 1991. Women's Labor and Pottery Production in Prehistory. In: Conkey, M. W. \& Gero, J. M. (Eds). Engendering Archaeology. Women and Prehistory. Oxford. Pp. 194223.

Øye, I. 1990. Middelalderkvinner i tverrfaglig belysning. Historisk tidsskrift 4:1990. Oslo. Pp. 435-455. 